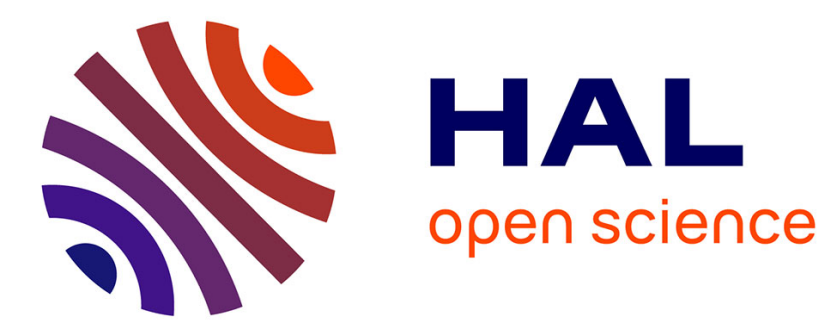

\title{
Intra-tourism trade, income distribution and tourism endowment: an econometric investigation
}

\author{
Joseph Hanna, L Lévi, Sylvain Petit
}

\section{To cite this version:}

Joseph Hanna, L Lévi, Sylvain Petit. Intra-tourism trade, income distribution and tourism endowment: an econometric investigation. Applied Economics, 2015, 47 (21), 10.1080/00036846.2015.1005817 . hal-01831500

\author{
HAL Id: hal-01831500 \\ https://hal.science/hal-01831500
}

Submitted on 5 Jul 2018

HAL is a multi-disciplinary open access archive for the deposit and dissemination of scientific research documents, whether they are published or not. The documents may come from teaching and research institutions in France or abroad, or from public or private research centers.
L'archive ouverte pluridisciplinaire HAL, est destinée au dépôt et à la diffusion de documents scientifiques de niveau recherche, publiés ou non, émanant des établissements d'enseignement et de recherche français ou étrangers, des laboratoires publics ou privés. 


\title{
Intra-tourism trade, income distribution and tourism endowment: an econometric investigation
}

\author{
J. Hanna ${ }^{\mathrm{a}}$, L. Lévi ${ }^{\mathrm{b}}$ and S. Petit ${ }^{\mathrm{c}, *}$ \\ a IDP, Université de Valenciennes et du Hainaut Cambrésis, Rue des cents têtes, France \\ ${ }^{b}$ IDP, Université de Valenciennes et du Hainaut Cambrésis, France \\ ${ }^{c}$ IDP, Université de Valenciennes et du Hainaut Cambrésis - EQUIPPE, France
}

\begin{abstract}
(Reference: Hanna J., Lévi L \& S. Petit (2015), «Intra-tourism trade, income distribution and tourism endowment: an econometric investigation», Applied Economics, 47(21):21842200
\end{abstract}

\begin{abstract}
Empirical investigation (Nowak et al., 2012) points out that vertical intra-industry trade (VIIT) in Europe is the dominant type of intra-industry trade (IIT) in the tourism sector. This article is the first in tourism literature to test separately the determinants of vertically and horizontally differentiated services, using the most recent models in the theory of IIT. We examine bilateral trade among all trading partners of the sample of European countries, covering the period 2000 to 2008. We show that differences in Gross Domestic Product (GDP) per capita and the income-distribution overlap, as well as cultural proximity, are the most significant driving forces behind VIIT for European countries. Geographic distance has a negative effect, whereas specific tourism endowments and relative size of the economies are less conclusive. These results confirm theory predictions and most of the empirical findings related to the pattern of VIIT for the manufacturing sector. As expected, we find that determinants of VIIT cannot explain horizontal intra-industry trade (HIIT) in tourism. We suggest two alternative methods of estimation: Generalized Least Squares (GLS) logistic function and the fractional logit estimator. We conclude that there are common factors explaining IIT in the manufacturing and tourism trades.
\end{abstract}

Key words: Intra-tourism trade, income distribution overlap, bilateral tourism flows, vertical differentiation, fractional-logit.

JEL Classification: C31, F14, L89

*Corresponding author. E-mail: sylvain.petit@univ-valenciennes.fr 


\section{Introduction}

The existence of IIT - defined as simultaneous exports and imports within the same industry - between countries of a similar level of development is one of the most important findings in the field of international trade since the 1960s. A great number of studies have confirmed the predominance of IIT for high-income and intermediateincome countries. Moreover, they found IIT to represent the most rapidly growing share of post-war trade between developed countries.

According to the United Nations World Tourism Organization (UNWTO, 2009) ${ }^{1}$, tourism accounted for roughly one third of total services exports in 2008. This share is likely to expand in the coming decade ${ }^{2}$, yet few studies are devoted to examining the determinants and the composition of these services in foreign trade. The widespread view of tourism trade is of a one-way flow, from source countries to highly tourism-specialized hosts. A careful examination of related data reveals a much more complex composition of trade in this sector. In a recent empirical contribution to the subject, Nowak et al. (2012) show that, with more than $58 \%$ of total tourism trade, IIT is the dominant pattern in Europe. Moreover the bulk of this trade is in vertically differentiated services. All the countries studied in their sample ${ }^{3}$ have a greater share of VIIT than HIIT in the total IIT of the tourism sector. However, these findings are not based on econometric modelling and do not provide an analysis of the driving forces behind tourism trade.

Despite the growing importance of services in foreign trade, only a few studies investigate the IIT share for these activities. Li et al. 2003, for instance, use an econometric approach to test the determinants of IIT in insurance. Tang (2003) implements analogous methods for telephone services, whereas Lee and Lloyd's (2002) study aggregates all services.

For the tourism industry, even less attention has been paid to IIT determinants. The results from Webster $e t$ al. (2007) suggest that IIT in tourism services is not consistent with the economies of developed countries. There are, however, some shortcomings in the analysis. The authors do not include, for instance, specific determinants of tourism trade (historic sites, and cultural or climate endowments). Likewise, the study does not use bilateral data to assess IIT. Hence, comparing one country's trade with the rest of the world may induce a bias if the data are aggregated on a geographic basis ${ }^{4}$. It is also worth noting that all studies devoted to services do not distinguish vertical and horizontal shares in total IIT.

In this article, we show that the determinants of VIIT in tourism are, to a large extent, similar to those found for the manufacturing sector. Our study focuses on 23 countries in Europe and covers the period 2000 to 2008. The approach we use has the following distinctive features:

- In the literature on the subject, most studies investigate trade between one country and a set of partners. The relationship between GDP per capita (used as a proxy for factor endowments, for instance) and VIIT may be ambiguous as it depends on the trading partner (Jensen and Lüthje, 2009; M. Cabral et al., 2013). In our study, we examine bilateral trade among all trading partners within the sample of countries. Such an empirical investigation has not yet been implemented in the tourism sector.

- On the demand side, in addition to differences in income levels, we introduce the income-distribution overlap from the theoretical model of Flam and Helpman (1987). The econometric studies by Durkin and Krygier (2000), Gabrisch (2006), and Jensen and Lüthje (2009) are among the few that assign a central role to differences in income distribution in explaining VIIT. However, none of these investigations deals with the tourism sector or with services in general.

- This article is also the first contribution in tourism literature to test separately the determinants of vertical and horizontal trade. In order to disentangle the two types of differentiated goods in total IIT, we implement the method introduced by Azhar and Elliott (2006). This method adds mathematical rigour to the commonly used measures ${ }^{5}$. Based on the Grubel-Lloyd (GL) index, it provides a continuous measure of the degree of vertical or horizontal quality of a product group.

- To add robustness to the econometric results, we use two alternative methods of estimation: a GLS logistic function and the fractional logit method suggested by Papke and Wooldridge (1996).

\footnotetext{
${ }^{1}$ The UNWTO 2009 report also states that tourism trade contributes up to $6 \%$ of total world exports of goods and services. It ranks as the fourth most exported item after fuel, chemicals and automotive parts.

${ }^{2}$ Tourism has experienced an annual growth rate exceeding $5 \%$ over the last 60 years.

${ }^{3}$ The sample was made up of 15 European Union (EU) countries, excluding Ireland, over the period 2000 to 2004

${ }^{4}$ A good treatment of this issue can be found in Fontagné and Freudenberg (1997).

${ }^{5}$ Further discussion of this method is given in section III. Abd-el-Rahman (1991), Greenaway et al. (1995), and Fontagné and Freudenberg (1997) distinguish the two components of IIT by using two closely related methods that differ in the way they define IIT.
} 
The econometric results reveal that the differences in GDP per capita, reflecting differences in factor endowments or in technology, and the income-distribution overlap are the most significant driving forces behind VIIT among European countries. Income distribution is, on the contrary, insignificant for HIIT, whereas GDP per capita is negatively correlated with this component of trade. Specific factors of the tourism industry are accounted for through two variables: historic and cultural endowment differences on one hand, and climate conditions on the other. However, these variables produce either unexpected or insignificant effects in our estimations. Cultural proximity (leading to similarity in consumption patterns) has a positive effect on both VIIT and HIIT.

Geographic distance shows, as expected, a negative relationship for both types of trade. The common currency has no effect on HIIT and shows, surprisingly, a negative relationship to VIIT. Finally, the relative size of the economies is somewhat ambiguous in explaining trade patterns in tourism.

The remaining part of the article is organized as follows. In section II, we discuss the theoretical foundations, as well as empirical applications, of VIIT in the related literature. Section III examines the measurement and the issues of disentangling IIT components. Explanatory variables and the econometric analysis are discussed in section IV. Results of the estimations are shown in section V, and section VI draws conclusions.

\section{Theoretical Foundations of VIIT}

Explanations of IIT based on early monopolistic competition models ${ }^{6}$ focus on trade in horizontally differentiated products. Exchanged goods are assumed to be close substitutes of similar quality, produced by the same increasing returns to scale technology. Empirical studies reveal, however, that trade in vertically differentiated commodities represents the dominant share of goods exchanged in most developed countries ${ }^{7}$. Nowak et al. (2012) find similar results for the tourism sector. The next generation of theoretical models for explaining IIT considers trade in vertically differentiated goods (e.g. VIIT in tourism). Trade involves the exchange of different qualities of the same commodity that use different technologies in their production process.

The relationship between differences in GDP per capita and bilateral IIT shares found in empirical works preceded the formal modelling of this relationship. Early studies support the inclusion of GDP per capita differences as explanatory variables of IIT in econometric investigations by referring to the Linder hypothesis. At the same time, the Helpman and Krugman (1985) model provided the formal justification for the negative relationship found between these variables, but for reasons other than similarities in demand patterns ${ }^{8}$. Some anomalous results of this relationship found in the literature - Hummels and Levinsohn (1995) - suggest an alternative modelling of demand ${ }^{9}$. Durkin and Krygier (2000) show that the positive relationship between GDP per capita and the share of IIT is consistent with vertically differentiated trade.

The theoretical foundation of VIIT lies in the work of Linder (1961), even though VIIT is not explicitly stated. It is nonetheless assumed that demand for quality of a given variety is increasing with the level of income. When we look at the demand side of the economy, we should also consider the pattern of income distribution. In a twocountry world, an overlap in income distribution determines whether there is a demand for a given product in both countries. It is expected that VIIT will dominate when countries have a large income-distribution overlap. Inside the overlap area, consumers with low income demand low-quality varieties, while the opposite occurs for high-income consumers. However, when the income-distribution overlap area is very thin, the low-quality commodities, for instance, which are demanded in the low-income country, are no longer demanded in the highincome country. In such a case, a variety of a given quality is not demanded in both countries, and trade in this variety will not occur. There are variable degrees of similarities (or differences) in income levels as well as in

\footnotetext{
${ }^{6}$ Examples are those of Krugman (1979, 1980, 1981), Lancaster (1980) and Helpman (1981).

${ }^{7}$ Greenaway et al. (1994, 1995), and Durkin and Krygier (2000) are among the significant contributions found in the literature.

${ }^{8}$ In the Helpman and Krugman model, increasing differences in the capital-to-labour ratio lowers the share of IIT. According to the degree of correlation between the capital/labour ratio and the GDP per capita, there will be a negative relationship between GDP per capita and the share of IIT.

${ }^{9}$ Hummels and Levinsohn (2005) found a negative relationship between GDP per capita differences and IIT using an Ordinary Least Squares regression. This relationship became positive when running regressions that control for country-specific fixed effects.
} 
income distribution among the trading partners in Europe. These two aspects of income are essential in modelling the demand side.

There are, however, factor-endowment as well as technological determinants of income differences. Modelling VIIT borrows from traditional trade theory - either a neo-Hecksher-Ohlin approach, as in Falvey and Kierzkowski (1987), or a neo-Ricardian framework, as in Flam and Helpman (1987).

From the factor-proportion theory, a capital-abundant country will have a relatively higher income per capita compared to a labour-abundant trading partner. Therefore, income depends on capital intensity and at the same time the quality content of product variety increases with capital intensity. It may be assumed that a relatively capital-abundant country produces high-quality varieties compared to a country with a lower capital-to-labour ratio.

One can expect, in empirical investigations, to establish a positive relationship between VIIT and differences in factor endowments, and a negative relationship for HIIT. Econometric results relative to VIIT do not always confirm these expectations. Greenaway et al. (1994, 1995), Blanes and Martin (2000) and Fukao et al. (2003) consider differences in GDP per capita as a proxy of differences in factor endowments, and find a negative relationship with VIIT. Gullstrand (2000), Martin-Montaner and Rios (2002), Durkin and Krygier (2000), and Crespo and Fontoura (2004) find that this variable is positive in their regressions.

Differences in factor endowments between two countries also mean differences in income per capita. Accordingly, we may expect that when factor-endowment differences are too large, the share of VIIT between the trading partners will be small. In an empirical study of trade between the EU and its major trading partners, Cabral et al. (2013) draw the conclusion that one should not expect a monotonic relationship between differences in factor endowments and VIIT. The authors distinguish two sets of countries: one with a higher and the other with a lower per capita income than the EU average. They establish a positive relationship between VIIT and differences in factor endowments for the high-income group, and a negative relationship for the other. This result suggests that the effect of differences in factor endowments on VIIT depends on the trading partner ${ }^{10}$.

In the Ricardian model of Flam and Helpman (1987), with a single factor input (labour), differences in technology explain one country's advantage in producing a higher quality of the differentiated product. In a monopolistic competition setting, quality differences are reflected in price and wage differences. The technologically advanced country will specialize in the high-quality range of varieties. Workers in this country will accordingly earn a higher wage. Durkin and Krygier (1997), in their test of the Flam and Helpman model for US trade with other Organisation for Economic Co-operation and Development (OECD) countries, consider GDP per capita as the expression of technological differences. They find a positive relationship between GDP per capita and VIIT.

The relationship between the trade pattern, the income-distribution overlap and the supply schedule is described in Fig. 1. For simplicity, we assume that the income distributions of the two countries (1 and 2) are represented by identical curves with different average incomes. The second country is identified by $*$ and the supply function is depicted by the heavy curve $Z(q)$. It is assumed in this example that country 1 specializes in high-quality goods (ranges of quality greater than $q^{e}$ ), whereas country 2 specializes in low-quality products (ranges of quality below $\left.q^{e}\right)^{11}$.

\footnotetext{
${ }^{10}$ This result is also confirmed by Jensen and Lüthje (2009).

${ }^{11} q^{e}$ is the level of quality that corresponds to the border delimiting the comparative advantages for the differentiated product between the two countries. At this level of quality, the consumer has no preference between the different sources of the product.
} 
Fig. 1: Area of income-distribution overlap and IIT, according to the model of Flam and Helpman (1987)

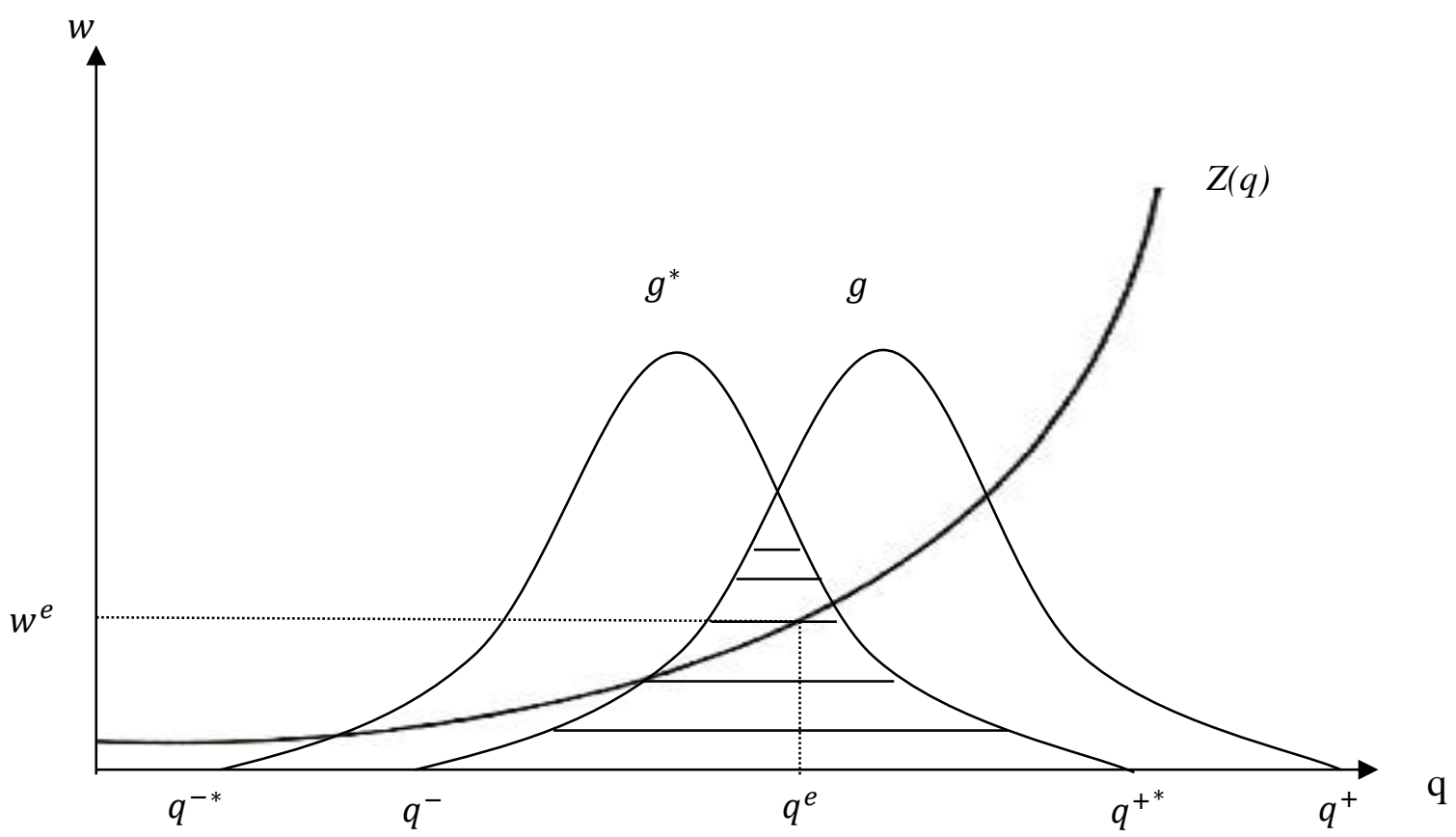

In such a situation, consumers of country 2 will demand from country 1 goods with quality belonging to the interval $\left[q^{e} ; q^{+^{*}}\right]$. Conversely, consumers of country 1 will demand from country 2 products with quality confined to the interval $\left[q^{-} ; q^{e}\right]$. Therefore, IIT is represented by the hatched area in the centre of Fig. 1. This example shows that the higher degree of similarity in income distribution, the higher is the share of VIIT $^{12}$.

It is common in empirical investigations to provide an analysis of trade between a reference country and a set of partners. We may observe some ambiguous results, as the relationship between

\footnotetext{
12 According to the model of Flam and Helpman (1987), the share of intra-industry trade in total trade between a home country and a foreign country (for which variables are noted by *) is given by: $S=\frac{\alpha+\gamma}{\alpha+\gamma^{*}} \frac{w L}{L^{*}} \frac{F\left(h_{d}\right)}{\left(1-F^{*}\left(h_{d}^{*}\right)\right)}$

The first ratio contains some parameters specific to the model (and the utility function); the second is the ratio comparing the economic sizes; and the last ratio is the degree of incomedistribution overlap. In the first ratio, $\alpha$ is a preference parameter given by the utility function. Convexity of the supply-schedule function $Z(q)=\frac{a^{*}(q)}{a(q)}$ is given by the parameters $\gamma$ and $\gamma^{*}$, which appear in equation $S$. It must be remembered that $a(q)$ and $a^{*}(q)$ are the unit labour requirements to produce the differentiated product of quality; $q$. $L$ and $L^{*}$ are the labour endowments in the respective countries; and $w, w^{*}$ are the corresponding wage rates. Finally, $h_{d}\left(\right.$ or $\left.h_{d}^{*}\right)$ is the distribution of income among social classes. They are also the expression of effective labour endowments for workers who address a demand for a product of quality $q_{d}$. Therefore, $F\left(h_{d}\right)$ and $F^{*}\left(h_{d}^{*}\right)$ are the functions of the cumulated distribution of income in the respective countries.
}

factor endowments and IIT depends on the trading partner. From the supply side, we should expect the share of VIIT to be small when differences in endowments (or in income) are excessively large. On one hand, rising differences in income levels increase the VIIT since these differences generate dissimilarities in demand. On the other hand, VIIT is more likely to be prominent between countries with a high degree of income-distribution overlap. Looking at the supply side alone is not sufficient to explain determinants of VIIT. We need to consider demand effects by including the incomedistribution overlap, as discussed above.

Countries with similar per capita income will have similar demand structures and will be inclined to exchange goods similar in quality. We should not expect HIIT and VIIT to behave in the same way regarding factor endowments, or technology and income-distribution differences. There are different determinants as well as empirical evidence that justify the separation of the two components of IIT.

\section{Horizontal and VIIT Measurement}

One of the earliest contributions in demonstrating the importance of IIT among developed countries is to be found in the empirical book of Grubel and 
Lloyd $(1975)^{13}$. The indicator they introduced still stands among the most widely used in measuring the intensity of two-way trade flows. The indicator gives the share of balanced trade (overlap between exports and imports) in total trade for a given industry $k$ between two countries, $i$ and $j$ :

$$
G L_{i j}^{k}=\frac{\left[\left(X_{i j}^{k}+M_{i j}^{k}\right)-\left|X_{i j}^{k}-M_{i j}^{k}\right|\right]}{X_{i j}^{k}+M_{i j}^{k}}=1-\frac{\left|X_{i j}^{k}-M_{i j}^{k}\right|}{X_{i j}^{k}+M_{i j}^{k}}
$$

$X_{i j}^{k}$ and $M_{i j}^{k}$ are respectively exports of product $k$ by country $i$ to country $j$, and imports of $k$ by $i$ from $j$. The measure given by the indicator is confined to the [l $\left.\begin{array}{ll}0 & 1\end{array}\right]$ interval. The greater its value, the larger is the share of balanced trade in total trade of product $k$ between the two countries. All trade is intraindustry when the indicator reaches the maximal value of 1 . This means that there are simultaneous flows between the two countries of the same amount of goods from the same industry. The opposite value 0 means that trade is exclusively of the inter-industry type. In this case, the output $k$ is either totally imported or exported by country $i$ against goods produced by a different industry.

Later developments in empirical studies focus on the separation of matched trade flows of similarquality goods (HIIT) from those of a different quality (VIIT). The two commonly used methodologies in the literature, which are also very similar, are those of Greenaway et al. (1994) on one hand, and Fontagné and Freudenberg (1997) on the other. The two approaches borrow from Abd-elRahman (1986, 1991).

Both groups of authors use the export-to-import unit value to reveal quality differences. For each product, a unit value $(U V)$ is calculated by dividing the monetary value of trade by the quantity, which gives a reasonable proxy of price ${ }^{14}$. The ratio of exports to imports (for instance) is thus obtained and a dispersion percentile, $\alpha$, is chosen to distinguish between horizontally and vertically differentiated products.

The two approaches are different in the way they define the degree of overlap between exports and

\footnotetext{
${ }^{13}$ Verdoorn (1960), Michaely (1962), Balassa (1966) and Finger (1967) proposed other indicators and methods to measure the intra-industry trade. The GL indicator has been preferred in the literature for two reasons: it gives a direct measure of the intraindustry trade intensity and it can be easily aggregated.

${ }^{14}$ The idea behind this assumption is that higher quality should command a higher price. Therefore, price can be considered an indicator of quality.
}

imports needed for trade to be considered as intraindustry. The method introduced by Greenaway et al. (1994) builds on the GL index. Greenaway et al. suggest the following condition on the value ratio to disentangle VIIT from HIIT:

$$
(1-\alpha) \leq \frac{U V_{i, j ; k}^{X}}{U V_{i, j k}^{M}} \leq(1+\alpha)
$$

Where $U V_{i, j, k}$ is the unit value of exports $X$ or imports $M$ in industry $k$.

$i$ and $j$ denote respectively the declaring country and its partner. The dispersion percentile, $\alpha$, takes any value between 0 and 1 .

Trade is considered to be vertically differentiated when the ratio lies outside the range defined in (2). Looking at the index from the home country side, exports are of high quality $\left(V I I T^{H}\right)$ if ${ }^{15}$ :

$$
\frac{U V^{X}}{U V^{M}}>(1+\alpha)
$$

Exports are of low quality $\left(V I I T^{L}\right)$ if the ratio is less than the other limit $(1-\alpha)$.

The GL measure is then split according to the following formula:

$$
G L=H I I T+V I I T^{H}+V I I T^{l}
$$

Numerous studies implement Greenaway et al.'s method, including those by Aturupane et al. (1999), Blanes and Martin (2000), and Gullstrand (2000). The choice of the threshold parameter $\alpha$ is arbitrary, but the commonly used values are 0.15 or 0.25 .

Fontagné and Freudenberg's method moves away from the standard GL index in defining IIT. These authors consider bilateral trade specific to an industry, and establish the distinction between oneway $(O W)$ and two-way $(T W)$ trade. An arbitrary value is chosen to distinguish between the types of trade flows. If imports, for instance, represent less than $10 \%$ of total trade, then they are considered the minority flows for this industry. In this case, trade is assumed to be an $O W$ flow $^{16}$. For values greater than $10 \%$, trade is of the $T W$ type. In addition, the method uses the same dispersion parameter, $\alpha$, as in Greenaway et al. (1994), to distinguish between the vertically differentiated two-way trade $(T W V D)$ and the horizontally differentiated component (TWHD) according to the following:

\footnotetext{
${ }^{15}$ Subscripts are dropped without loss of generality.

16 The opposite conclusion then holds for exports that are considered to be majority flows. In either case, there is one-way trade for this industry.
} 


$$
\frac{1}{(1+\alpha)} \leq \frac{U V^{X}}{U V^{M}} \leq(1+\alpha)
$$

When condition (3) holds, there is a two-way trade in horizontally differentiated goods. Bilateral trade for any industry is split in the following way: $O W+T W V D+T W H D=1$.

The difference between conditions (2) and (3) lies in the left-hand boundary. It ensures symmetry between the lower and upper limits relative to their distance from unity. In addition to Fontagné et al. (1997), the European Commission (1996) also relies on this method in measuring IIT.

As conditions given by the two methods are different, it is no longer possible to compare directly results provided by these alternative measures for separating horizontal from vertical differentiated trade. As Azhar and Elliott (2006) put it, for $\alpha=15 \%$, a unit-value ratio of 0.86 will appear as $V_{I I T}{ }^{L}$ using Fontagné and Freudenberg's method, but as HIIT using Greenaway et al.'s method.

The shortcoming of these methods, according to Azhar and Elliott, lies in using simple unit-value ratios to define boundaries between product-quality types. The method they introduce to measure and to compare product-quality differences is based on the traditional GL index. They construct two related indexes of quality differentiation that have symmetrical limits and are projected, or scaled equally on both lower and upper limits, to define a 'product-quality space'.

The first index is very similar to the GL indicator. It measures the dispersion of horizontally differentiated products in total IIT flows:

$$
P Q H_{i, j}^{k}=1-\frac{U V_{i, j, k}^{X}-U V_{i, j, k}^{M}}{U V_{i, j, k}^{X}+U V_{i, j, k}^{M}}
$$

$U V_{i, j, k}$ is the unit value of export $X$ or import $M$ in industry $k$. $i$ and $j$ respectively denote the declaring country and its partner. By definition, the following set of inequalities is satisfied:

$$
0 \leq P Q H_{i, j}^{k} \leq 2
$$

The second index measures the dispersion of quality of vertically differentiated products in total IIT flows:

$$
P Q V_{i, j}^{k}=1+\frac{U V_{i, j, k}^{X}-U V_{i, j, k}^{M}}{U V_{i, j, k}^{X}+U V_{i, j, k}^{M}}
$$

with $0 \leq P Q V_{i, j}^{k} \leq 2$ and $P Q V_{i, j}^{k}+P Q H_{i, j}^{k}=2$

If the qualities of the products exchanged are strictly identical, then $P Q V$ and $P Q H$ are equal to 1 . A degree of arbitrariness emerges when it comes to deciding what stands for horizontal or vertical trade flows. As quality reflects price, it is intuitively appropriate to consider similarity in costs as a measure to select the cut-off point. It is assumed, for instance, that when the imports and exports of a product share at least $85 \%$ of their cost, there is a two-way trade in horizontally differentiated products $^{17}$.

From the perspective of the home country, IIT flows are similar in quality (there is HIIT) if: $0.85 \leq P Q H \leq 1.15$ The condition on the other index also holds: $0.85 \leq P Q V \leq 1.15$.

For the cut-off point of $85 \%$, the reasoning is as follows:

For the $P Q H$ index, IIT is high quality, therefore $V I I T^{H}$, if $P Q H<0.85$, or low quality $\left(V_{I I T}{ }^{L}\right)$ if $P Q H>1.15$.

In a similar way, IIT is considered as high quality if $P V Q>1.15$ and low quality if $P V Q<0.85$. When the $P V Q$ index lies between these two values, imports and exports are horizontally differentiated in the two-way trade.

\section{The Econometric Analysis}

\section{Independent variable and sample choices}

The overall sample is a set of European countries during the period 2000 to $2008^{18}$. The countries and

\footnotetext{
17 The results with the $15 \%$ threshold remain consistent with the larger dispersion factor of $25 \%$; they are mostly selected and implemented by the other two methods. This is another important advantage of the methodology introduced by Azhar and Elliott.

${ }^{18}$ Ireland, the United Kingdom, France, Germany, Italy, Spain, Portugal, Greece, Denmark, Sweden, Switzerland, Finland, Norway, Hungary, Slovenia, Estonia, Belgium, Luxembourg, the Netherlands, Austria, Poland, Slovakia and the Czech Republic.
} 
period were chosen based on data availability. The dependent variable is made up of the GL indexes based on bilateral intra-European trade flows in tourism services (OECD, 2002, 2008). The method suggested by Lejour and Verheijden $(2004)^{19}$ was used to provide the harmonized data. Elements of the GL indicator, given by equation 1 , were described in section III. After some data-cleaning operations ${ }^{20}$, we are left with a sample made up of 2726 GL indicators.

The mean value of these indicators is approximately $57 \%$, which shows a strong proportion of two-way trade in the tourism sector ${ }^{21}$. These flows are particularly meaningful for the following pairs of countries: Spain/Portugal (96\%), Finland/Sweden (92\%), Germany/Switzerland (92\%), France/Italy (92\%) and Austria/Slovakia (89\%). Conversely, the intensity of IIT in tourism is particularly weak for some other bilateral relationships, such as Norway/Switzerland (8\%), Norway/Spain (9\%), Denmark/Spain (13\%), Germany/Spain (16\%) and Finland/Greece (17\%).

From this point of the study, we focus on a set of three subsamples: total, horizontal and vertical flows of IIT in tourism. Studying the last two subsamples is intended to identify the determinants of the two types of IIT in tourism. In order to distinguish between the vertical and the horizontal components, we use the method suggested by Azhar and Elliott (2006), discussed in section III. As the unit value of tourism exports, we select the cost of an overnight stay, net of differences in the cost of living ${ }^{22}$. According to our results, vertical differentiation appears as the dominant type of IIT in tourism within our sample of European countries (with $75 \%$ of pairs of countries being considered as vertically differentiated).

\section{Explanatory variables}

\section{Income-distribution-overlap variable and absolute differences in GDP per capita}

Overlap $W_{i j t}$ and $D G D P C_{i j t}$

Our first major explanatory variable, the incomedistribution overlap, is borrowed from the

\footnotetext{
19 The results of data harmonization are available on request from the authors. For further details regarding the method, the reader may refer to Nowak et al. (2012).

20 These involve correcting or suppressing some inconsistent data.

${ }^{21}$ For more details relative to the description of the statistics, see Nowak et al. (2012), where a similar sample is studied.

${ }^{22}$ The principle is based on the Purchasing Power Parity (PPP) indicator from the CHELEM database by CEPII. Computational details are available from the authors on request. The data on overnight stays are from UNWTO (2012).
}

theoretical model of Flam and Helpman (1987) ${ }^{23}$. As we use bilateral observations, the degree of similarity in income distribution between a country and each of its partners is measured separately. For this purpose, we use income-distribution data by decile for the European countries in the sample. These data are collected from the Luxembourg Income Study and Eurostat. The information they provide is the average income by decile for each country $^{24}$.

The measure of the variable is calculated as follows: $p_{1}$ denotes the proportion of the population in the poorer country that has an income below the $10 \%$ decile of the income distribution of the richer country; and $\mathrm{p}_{2}$ denotes the proportion of the population in the richer country that has an income above the $10 \%$ decile of the income distribution of the poorer country ${ }^{25}$. Accordingly, the incomedistribution-overlap variable is expressed as:

$$
\text { Overlap } W_{i j t}=1-\frac{\left(p_{1}+p_{2}\right)}{2}
$$

The values of our variable span the interval ranging from 0 to 1 . If the income distributions are different among the countries, then both $\mathrm{p}_{1}$ and $\mathrm{p}_{2}$ will be large, and the value of the variable will be near to 0 . In contrast, if the income distributions are identical, then both $\mathrm{p}_{1}$ and $\mathrm{p}_{2}$ will be small, and the value of the variable will be close to 1 . This variable gives a direct measure of the income-distribution overlap ${ }^{26}$.

Fig. 2 shows the overlap variable distribution for the sample used.

\footnotetext{
${ }^{23}$ This is described in section II.

${ }^{24}$ For the missing data relating to some years, we have assumed that the ratios of the average income for one decile to the total average income of the population have (for the period covered by the study) developed in the same way as in earlier years. In this way, it is possible to estimate for each country the average income of every decile of the population of the sample of countries for the period 2000 to 2008 .

${ }^{25}$ In this case, we have 20 deciles for each two countries.

${ }^{26}$ In practice, the maximum value of $\mathrm{p}_{1}$ and $\mathrm{p}_{2}$ is 0.9 , and the minimum value is 0.1 .
} 


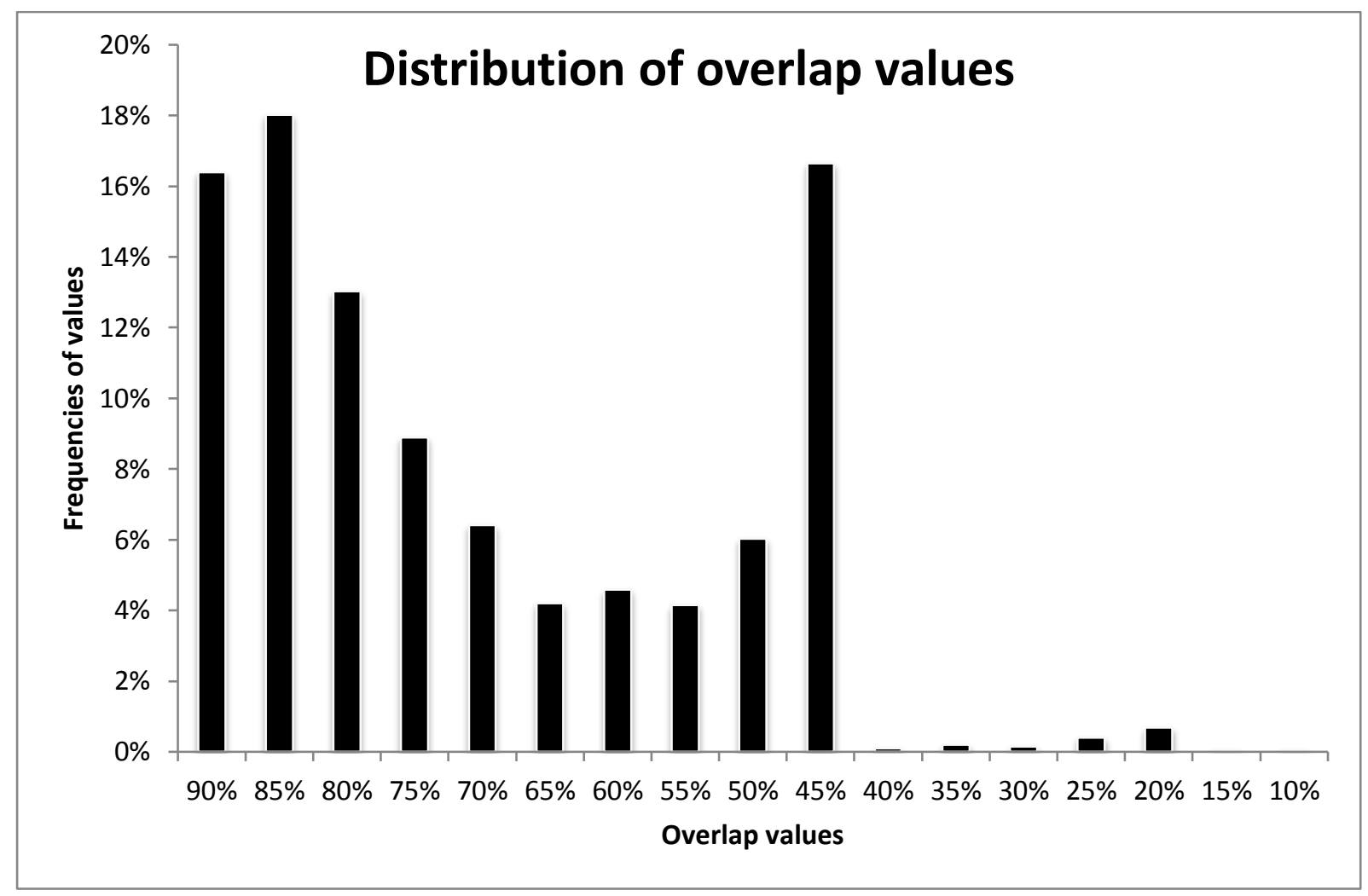

Fig. 2: Distribution of overlap values

The pattern depicted by this distribution may well be explained by the process of economic integration and income-distribution policies that tend to reduce differences in the standard of living across Europe. The values of this variable are accordingly high (the average is equal to $70 \%$ ) for the sample of countries we use. Following Flam and Helpman's (1987) analysis, we expect that similarity in income distributions also favours VIIT in the tourism sector.

The other variable we consider as essential in explaining VIIT is the absolute difference in GDP per capita ${ }^{27}$. Following the literature, GDP per capita may serve as a proxy for either relative factor endowments or technological differences. From the discussion in section II, we expect a positive relationship between this variable and VIIT (and a negative relationship to HIIT) for countries with comparable levels of development. The data for this variable are extracted from the CHELEM database by CEPII.

\footnotetext{
${ }^{27}$ This is the GDP/PPP divided by the level of the population.
}

\section{Tourism-endowment variables}

$$
\text { Diffendo } 1_{i j t}, \text { Diffendo } 2_{i j t}
$$

We introduce two complementary supply-side variables in order to account for sector-specific endowments. The first of these is related to historical and natural tourism resources. It is somewhat obvious to observe that history, natural sites and culture make up each country's distinctive endowments. For practical reasons, we link this variable to the number of sites that appear on UNESCO's World Heritage list ${ }^{28}$. The other endowment variable hinges on climate considerations. To capture the latter, we focus on the weather conditions normally prevailing in the capital of the country and record the number of rainy days through the year ${ }^{29}$. Data relative to climate were gathered by the organization Weather Online.

${ }^{28}$ This is the only information that allows us to measure this set of endowments. Moreover, our study concerns only European countries that have broadly similar lobbying power. Therefore, the estimation bias, relative to lobbying, in measuring tourism heritage endowments is quite weak.

${ }^{29}$ This is the only type of climatic variable available for the sample studied. 
For the first endowment variable, we use the absolute differences in the number of sites between two countries. As for the other, we account for differences in the number of days of 'good weather'. These two variables are likely to induce a positive impact on tourism trade as a whole. However, we cannot clearly predict what effect they produce on either VIIT or HIIT $^{30}$.

\section{Distance variables}

Dist $_{i j}$, ComRel $_{i j t}$, ZonEuro $_{i j t}$

The first variable is the geographic distance separating the countries. It may be assumed that countries lying close to each other benefit from lower transport and information costs relative to tourism destinations. These factors reasonably favour IIT in tourism. We use distance weighted by the geographic distribution of population to express this variable, for which data are available from CEPII.

Countries close to each other geographically will tend to have similar demand patterns due to linguistic and cultural similarities. The latter are thereby strongly correlated with geographic distance. Attempts to measure cultural proximity, and its effect on IIT, are found in Disdier et al. (2010), who rely on bilateral cultural-goods trade ${ }^{31}$, and in Felbermayr and Toubal (2010), who use bilateral scores data from the Eurovision Song Contest $^{32}$. The relationship they use is somewhat loose in measuring the impact on tourism activities. It is unclear what effect a once-yearly event, occurring in different locations in Europe, may have on consumers' behaviour in terms of seeking quality-differentiated goods and services.

The common cultural variable we introduce is rooted in historic links and is not biased by geographic distance. Cultural proximity based on religious affiliation may reveal similarities (or differences) in consumer preferences. Similar consumption (or saving) behaviour is likely to produce a positive impact on total IIT in the tourism sector.

For European countries, Christianity is the most widely spread religion. From this common faith, we can distinguish five branches: Roman Catholic, Protestant, Orthodox, Anglican and Lutheran. We introduce a dummy variable to capture religious proximity. If two countries are affiliated to the same major church (in terms of the proportion of followers in the total population), the variable is set to 1 , and otherwise 0 . The data were collected from

\footnotetext{
${ }^{30}$ This issue is picked up later, in section $\mathrm{V}$ (on results).

${ }^{31}$ There is already a good share of cultural trade in tourism trade.

${ }^{32}$ This is a very popular pan-European television show.
}

the Central Intelligence Agency's World Factbook. We may expect a positive impact of cultural similarities on IIT in tourism activities. It is, however, difficult to predict the effects on the two components of this trade.

Finally, we introduce a dummy variable with reference to the Eurozone to assess whether or not common currency favours IIT in tourism. It is defined by 1 if the two countries belong to this zone, and 0 if not. We would expect the common currency to have a positive impact on tourism mobility.

\section{Other control variables}

$$
\operatorname{MaxGDP}_{i j t}, \operatorname{MinGDP}_{i j t}
$$

The additional control variables we introduce are quite commonly used by econometric studies in the field of IIT (Fontagné et al., 1997; Durkin and Krygier, 2000; Lee and Lloyd, 2002; Gabrisch, 2006). The Min and Max GDP variables are proxies for size differences in terms of total GDP. MinGDP, for instance, is the lower of the GDPs from two countries ${ }^{33}$. Small differences represent similarity in consumer tastes and so enhance HIIT. For the manufacturing sector, we would expect a positive value for the MinGDP variable on HIIT. For VIIT, the literature does not provide any clear prediction for the Min/Max GDP relationship ${ }^{34}$. However, empirical studies show that most relationships have opposite values for VIIT and HIIT. Moreover, for tourism trade, there is no evidence that absolute or relative size of trading partners induces an impact on intra-tourism flows. One cannot predict clearly whether these variables will be positive or negative.

Table 1 summarizes the expected signs of the explanatory variables following the type of IIT (total, HIIT and VIIT). As VIIT is the dominant share of total IIT, both are expected to bear the same sign.

\footnotetext{
${ }^{33}$ Alternatively, the Max GDP chooses the larger GDP.

34 In the manufacturing sector, the absolute size of trading partners matters for VIIT. A given product is more likely to be produced in a large economy due to the diversity of the industrial activities. For VIIT to exist for a given product, both partners have to produce it, as discussed in section II.
} 
Table 1: Signs expected from the estimations

\begin{tabular}{|c|c|c|c|}
\hline & VIIT & HIIT & Total IIT \\
\hline Overlap $_{i j t}$ & + & $?$ & + \\
\hline DGDPC \\
$i j t$ & + & - & - \\
\hline Diffendo $_{i j t}$ & $?$ & $?$ & - \\
\hline Diffendo $_{i j t}$ & $?$ & $?$ & $+(?)$ \\
\hline MaxGDP $_{i j t}$ & $+(?)$ & $+(?)$ & $-(?)$ \\
\hline MinGDP $_{i j t}$ & $-(?)$ & - & - \\
\hline Dist $_{i j}$ & - & $?$ & + \\
\hline ComRel $_{i j t}$ & $?$ & + & + \\
\hline ZonEuro $_{i j t}$ & + & $-(?)$ & $+(?)$ \\
\hline MaxGDP $_{i j t}$ & $+(?)$ & $+(?)$ & $-(?)$ \\
\hline MinGDP $_{i j t}$ & $-(?)$ & & + \\
\hline
\end{tabular}

Lastly, we made sure that multicollinearity was ruled out between the independent variables or explanatory variables; this would otherwise introduce a statistical bias to the estimations. To avoid this problem, we reverted to the use of variance inflation factors (VIFs) ${ }^{35}$. This test is often used to detect the collinearity of the exogenous variables with the constant. VIF values greater than 10 need further examination.

\section{Econometric method implemented}

In this article, we lay down estimations for three types of IIT in tourism: total, vertical and horizontal. The method usually implemented ${ }^{36}$ involves a logistic specification that enables us to deal with the fact that the endogenous variable is bounded by 0 and 1 . The relationship takes the following form:

$G L_{i j t}=\frac{1}{1+\exp \left(-b-A X_{i j t}\right)}+\varepsilon_{i j t}$

$A X_{i j t}=a_{1}$ Overlap $W_{i j t}+$

$a_{2} D G D P C_{i j t} a_{3}$ Diffendo $1_{i j t}+$

$a_{4}$ Diffendo $_{i j t}++a_{5}$ Dist $_{i j}+a_{6}$ ComRel $_{i j t}+$

$a_{7}$ ZonEuro $_{i j t}+a_{8} \max G D P_{i t}+a_{9} \operatorname{minGDP} P_{j t}$

\footnotetext{
${ }^{35} \mathrm{~A}$ Variance Inflation Factor for variable $j$ is given by $\operatorname{VIF}(j)=$ $\frac{1}{1-R^{2}(j)}$, where $R(j)$ is the coefficient of the multiple correlation between the $j$ variable and the other explanatory or independent variables. The higher the value of $V I F$, the more the variables are correlated.

${ }^{36}$ The reader may refer to Loertscher and Wolter (1980), Balassa and Bauwens (1987), Hummels and Levinsohn (1995), Fontagné et al. (1997), Durkin and Krygier (2000), Lee and Lloyd (2002), and Gabrisch (2006).
}

We encounter a difficulty in the choice of the estimator because the statistic of the White test reveals that we cannot accept the null hypothesis of homoscedasticity. To overcome this problem, we perform econometric estimations by using two alternative methods. The most common way to deal with unknown heteroscedasticity is to use the GLS method with a robust estimator of the covariance matrix along the lines of Eicker-White (Eicker, 1963; White, 1980).

The other approach explored in this article is the fractional logit method introduced by Papke and Wooldridge (1996). This method is particularly suited to estimating a model where the endogenous variable does not show a normal distribution. This is comparable to the case of models that involve mass proportions because the values of the GL indicator for tourism are mainly congregated on the outer limits of the interval [0 1], with only a few values in-between. This method hinges on a maximum likelihood estimator of a logistic model and a Bernoulli-type distribution.

Some countries are more inclined than others to show balanced bilateral trade in tourism. To take this into account, we introduce fixed-effects variables. These are better suited to capturing the unique features of specific countries, in contrast to explanatory variables (which, in this model, capture the characteristics of pairs of countries).

For the three subsamples - total, vertical and horizontal IIT in tourism - we accordingly perform two estimations: GLS with a logistic specification for the first method, and the fractional logit for the other. In conclusion, we have 12 regressions to 
interpret (two methods times three subsamples, with and without fixed effects).

\section{Results}

The tables given below gather the econometric results for global IIT, HIIT and VIIT in tourism. For both methods implemented - GLS with a logistic specification and fractional logit - we compare outcomes, with or without the introduction of fixed-effects variables. The results show clearly that $\mathrm{R}^{2}$ reaches a lower value when fixed effects are not accounted for. This result is due to the high variance of the GL values of the dependent variable (the coefficient of variation being approximately $50 \%)$.

Table 2: Econometric results on global IIT in tourism

\begin{tabular}{|c|c|c|c|c|}
\hline Variables & $\begin{array}{c}\text { GLS } \\
\text { logistic }\end{array}$ & $\begin{array}{c}\text { GLS } \\
\text { logistic }\end{array}$ & Fractional logit & Fractional logit \\
\hline Constant & $\begin{array}{c}0.6642926^{\text {**** }} \\
(4.49)\end{array}$ & $\begin{array}{c}-2.064377^{* *} \\
(-2.08)\end{array}$ & $\begin{array}{c}0.4910292^{* * * *} \\
(4.61)\end{array}$ & $\begin{array}{c}-1.480757^{* *} \\
(-2.14)\end{array}$ \\
\hline Overlap $W_{i j t}$ & $\begin{array}{c}0.2335892 \\
(1.39)\end{array}$ & $\begin{array}{c}0.3940911^{*} \\
(1.77)\end{array}$ & $\begin{array}{l}0.2243163^{*} \\
\quad(1.85)\end{array}$ & $\begin{array}{c}0.3162789^{* *} \\
(1.97)\end{array}$ \\
\hline$D G P D C_{i j t}$ & $\begin{array}{c}-0.0019768 \\
(-0.77)\end{array}$ & $\begin{array}{c}0.0082706^{* * *} \\
(2.89)\end{array}$ & $\begin{array}{c}-0.0002053 \\
(-0.11)\end{array}$ & $\begin{array}{c}0.0068543^{* * *} \\
\quad(3.21)\end{array}$ \\
\hline DiffEndol $_{i j t}$ & $\begin{array}{l}-0.0055879^{* *} \\
(-2.11)\end{array}$ & $\begin{array}{c}0.006025^{* *} \\
(2.08)\end{array}$ & $\begin{array}{c}-0.0055509^{* * *} \\
(-2.97)\end{array}$ & $\begin{array}{c}0.0022777 \\
(1.10)\end{array}$ \\
\hline DiffEndo $2_{i j t}$ & $\begin{array}{c}0.00055 \\
(1.04)\end{array}$ & $\begin{array}{c}-0.0006019 \\
(-1.05)\end{array}$ & $\begin{array}{c}0.000102 \\
(0.27)\end{array}$ & $\begin{array}{c}-0.0006557 \\
(-1.56)\end{array}$ \\
\hline Dist $_{i j}$ & $\begin{array}{c}-0.0005994^{\text {**** }} \\
(-12.73)\end{array}$ & $\begin{array}{c}-0.0007543^{\text {**** }} \\
(-9.01)\end{array}$ & $\begin{array}{c}-0.0004665^{\text {**** }} \\
(-13.61)\end{array}$ & $\begin{array}{c}-0.0005827^{* * * *} \\
(-9.82)\end{array}$ \\
\hline ComRel $_{i j t}$ & $\begin{array}{c}0.4118221^{* * * *} \\
(6.08)\end{array}$ & $\begin{array}{c}0.5839128^{* * * *} \\
(6.82)\end{array}$ & $\begin{array}{c}0.2906567^{* * * *} \\
(5.97)\end{array}$ & $\begin{array}{c}0.3958898^{* * * *} \\
(6.41)\end{array}$ \\
\hline ZonEuro $_{i j t}$ & $\begin{array}{c}-0.3582726^{\text {**** }} \\
(-5.04)\end{array}$ & $\begin{array}{c}-0.2892182^{* * * *} \\
(-2.61)\end{array}$ & $\begin{array}{c}-0.2756068^{* * *} \\
(-5.37)\end{array}$ & $\begin{array}{c}-0.2740087^{* * * *} \\
(-3.35)\end{array}$ \\
\hline $\max G D P_{i t}$ & $\begin{array}{c}3.52 \mathrm{e}-10^{* * * *} \\
(8.38)\end{array}$ & $\begin{array}{l}1.14 \mathrm{e}-09^{* * * *} \\
\quad(3.47)\end{array}$ & $\begin{array}{c}2.21 \mathrm{e}-10{ }^{* * * *} \\
(7.55)\end{array}$ & $\begin{array}{c}8.15 \mathrm{e}^{-}-10^{* * * *} \\
\quad(3.52)\end{array}$ \\
\hline $\min G D P_{j t}$ & $\begin{array}{c}-1.86 \mathrm{e}^{-}-10^{* * *} \\
(-1.97)\end{array}$ & $\begin{array}{c}6.20 \mathrm{e}-10 \\
(1.79)\end{array}$ & $\begin{array}{c}-9.70 e^{-11} \\
(-1.45)\end{array}$ & $\begin{array}{l}4.95 \mathrm{e}-10^{* *} \\
\quad(2.07)\end{array}$ \\
\hline $\mathrm{R}^{2}$ & $13.83 \%$ & $26.40 \%$ & - & - \\
\hline $\begin{array}{l}\text { Log-likelihood } \\
\text { Fixed effects } \\
\text { Sample size }\end{array}$ & $\begin{array}{c}- \\
\text { No } \\
2726\end{array}$ & $\begin{array}{c}- \\
\text { Yes }\end{array}$ & $\begin{array}{c}-1340.97393 \\
\text { No } \\
2726\end{array}$ & $\begin{array}{c}-1289.234241 \\
\text { Yes } \\
2726\end{array}$ \\
\hline
\end{tabular}

Notes: $* * *, * *$ and $*$ indicate that coefficients are significantly different from zero at the $1 \%, 5 \%$ and $10 \%$ levels respectively T-statistic is in parentheses. 
Table 3: Econometric results on HIIT in tourism

\begin{tabular}{|c|c|c|c|c|}
\hline Variables & $\begin{array}{c}\text { GLS } \\
\text { logistic }\end{array}$ & $\begin{array}{c}\text { GLS } \\
\text { logistic }\end{array}$ & Fractional logit & Fractional logit \\
\hline Constant & $\begin{array}{c}1.046669^{* * * *} \\
(3.35)\end{array}$ & $\begin{array}{c}-4.302347 \\
(-1.71)\end{array}$ & $\begin{array}{c}0.7778275^{* * * *} \\
(3.46)\end{array}$ & $\begin{array}{c}-5.445115^{* * * *} \\
(-3.14)\end{array}$ \\
\hline Overlap $W_{i j t}$ & $\begin{array}{c}-0.3679051 \\
(-1.16)\end{array}$ & $\begin{array}{l}0.1934403 \\
\quad(0.50)\end{array}$ & $\begin{array}{c}-0.2507413 \\
(-1.12)\end{array}$ & $\begin{array}{l}0.2846188 \\
\quad(1.04)\end{array}$ \\
\hline$D G D P C_{i j t}$ & $\begin{array}{c}-0.0096716^{*} \\
(-1.81)\end{array}$ & $\begin{array}{c}0.0082706^{* * * *} \\
(2.89)\end{array}$ & $\begin{array}{c}-0.0063287^{*} \\
(-1.68)\end{array}$ & $\begin{array}{c}0.0068543^{\text {*** }} \\
(3.21)\end{array}$ \\
\hline DiffEndo $_{i j t}$ & $\begin{array}{c}-0.0144719^{* * *} \\
(-2.18)\end{array}$ & $\begin{array}{l}0.0003833 \\
\quad(0.06)\end{array}$ & $\begin{array}{c}-0.0127593^{* * * *} \\
(-2.82)\end{array}$ & $\begin{array}{c}-0.0019468 \\
(-0.44)\end{array}$ \\
\hline DiffEndo $2_{i j t}$ & $\begin{array}{c}-0.0002273 \\
(-0.19)\end{array}$ & $\begin{array}{c}-0.0004954 \\
(-0.37)\end{array}$ & $\begin{array}{c}-0.0004083 \\
(-0.50)\end{array}$ & $\begin{array}{c}-0.0003279 \\
(-0.36)\end{array}$ \\
\hline Dist $_{i j}$ & $\begin{array}{c}-0.0004514^{* * *} \\
(-4.45)\end{array}$ & $\begin{array}{c}-0.0004697^{\text {*** }} \\
(-2.97)\end{array}$ & $\begin{array}{c}-0.000358^{* * *} \\
(-5.13)\end{array}$ & $\begin{array}{c}-0.0002991^{* * *} \\
(-2.50)\end{array}$ \\
\hline ComRel $_{i j t}$ & $\begin{array}{c}0.6014982^{* * * *} \\
\quad(4.07)\end{array}$ & $\begin{array}{l}1.022667^{* * * *} \\
\quad(7.70)\end{array}$ & $\begin{array}{c}0.3936909^{* * *} \\
(3.88)\end{array}$ & $\begin{array}{c}0.8236333^{* * *} \\
(8.26)\end{array}$ \\
\hline ZonEuro $_{i j t}$ & $\begin{array}{c}-0.0336381 \\
(-0.23)\end{array}$ & $\begin{array}{l}0.0241633 \\
(0.09)\end{array}$ & $\begin{array}{c}0.065566 \\
(0.63)\end{array}$ & $\begin{array}{l}0.1110471 \\
\quad(0.59)\end{array}$ \\
\hline $\max G D P_{i t}$ & $\begin{array}{l}5.91 \mathrm{e}-10^{* * * *} \\
\quad(5.37)\end{array}$ & $\begin{array}{c}2.23 \mathrm{e}-09^{* * *} \\
(2.65)\end{array}$ & $\begin{array}{l}3.26 \mathrm{e}-10^{* * * *} \\
\quad(4.48)\end{array}$ & $\begin{array}{c}2.40 \mathrm{e}-09^{* * * *} \\
(3.99)\end{array}$ \\
\hline $\min G D P_{j t}$ & $\begin{array}{c}-9.66 \mathrm{e}-10^{* *} \\
(-2.08)\end{array}$ & $\begin{array}{c}3.78 \mathrm{e}-10 * \\
(0.34)\end{array}$ & $\begin{array}{c}-4.54 \mathrm{e}-10^{* * *} \\
(-1.36)\end{array}$ & $\begin{array}{c}1.22 \mathrm{e}^{-}-09 \\
(1.53)\end{array}$ \\
\hline $\mathrm{R}^{2}$ & $12.46 \%$ & $53.20 \%$ & - & - \\
\hline Log-likelihood & - & - & -347.2470813 & -295.2824464 \\
\hline $\begin{array}{l}\text { Fixed effects } \\
\text { Sample size }\end{array}$ & $\begin{array}{l}\text { No } \\
699\end{array}$ & $\begin{array}{l}\text { Yes } \\
699\end{array}$ & $\begin{array}{l}\text { No } \\
699\end{array}$ & $\begin{array}{l}\text { Yes } \\
699\end{array}$ \\
\hline
\end{tabular}

Notes: $* * *, * *$ and $*$ indicate that coefficients are significantly different from zero at the $1 \%, 5 \%$ and $10 \%$ levels respectively.

T-statistic is in parentheses. 
Table 4: Econometric results on VIIT in tourism

\begin{tabular}{|c|c|c|c|c|}
\hline Variables & $\begin{array}{c}\text { GLS } \\
\text { logistic }\end{array}$ & $\begin{array}{c}\text { GLS } \\
\text { logistic }\end{array}$ & Fractional logit & Fractional logit \\
\hline Constant & $\begin{array}{l}0.4415584^{* *} \\
(2.53)\end{array}$ & $\begin{array}{c}0.0756133 \\
(0.07)\end{array}$ & $\begin{array}{c}0.2950437^{* * *} \\
(2.33)\end{array}$ & $\begin{array}{c}0.5746369 \\
(0.76)\end{array}$ \\
\hline Overlap $W_{i j t}$ & $\begin{array}{l}0.4465175^{* *} \\
\quad(2.26)\end{array}$ & $\begin{array}{l}0.5726048^{* *} \\
\quad(2.07)\end{array}$ & $\begin{array}{l}0.414261^{* * * *} \\
\quad(2.89)\end{array}$ & $\begin{array}{c}0.4454572^{* * *} \\
(2.23)\end{array}$ \\
\hline$D G D P C_{i j t}$ & $\begin{array}{c}0.000218 \\
(0.08)\end{array}$ & $\begin{array}{l}0.0078106^{* *} \\
\quad(2.31)\end{array}$ & $\begin{array}{l}0.0014061 \\
(0.66)\end{array}$ & $\begin{array}{c}0.0067149^{* * *} \\
(2.63)\end{array}$ \\
\hline DiffEndo $_{i j t}$ & $\begin{array}{c}-0.0024792 \\
(-0.88)\end{array}$ & $\begin{array}{l}0.0035168 \\
(1.08)\end{array}$ & $\begin{array}{c}-0.0030402 \\
(-1.50)\end{array}$ & $\begin{array}{l}0.0007743 \\
(0.33)\end{array}$ \\
\hline DiffEndo $2_{i j t}$ & $\begin{array}{c}0.0016263^{* * * *} \\
(2.62)\end{array}$ & $\begin{array}{c}0.000735 \\
(1.07)\end{array}$ & $\begin{array}{l}0.0009249^{* * *} \\
\quad(2.11)\end{array}$ & $\begin{array}{c}0.0003454 \\
(0.68)\end{array}$ \\
\hline Dist $_{i j}$ & $\begin{array}{c}-0.0006249^{* * * *} \\
(-11.50)\end{array}$ & $\begin{array}{c}-0.0008553^{* * * *} \\
(-7.93)\end{array}$ & $\begin{array}{c}-0.0004844^{* * * *} \\
(-12.04)\end{array}$ & $\begin{array}{c}-0.0006318^{* * * *} \\
(-8.25)\end{array}$ \\
\hline ComRel $_{i j t}$ & $\begin{array}{c}0.3587074^{* * *} \\
\quad(4.76)\end{array}$ & $\begin{array}{c}0.4002882^{* * * *} \\
(3.46)\end{array}$ & $\begin{array}{c}0.2695039^{* * *} \\
(4.88)\end{array}$ & $\begin{array}{l}0.280596^{* * *} \\
\quad(3.42)\end{array}$ \\
\hline ZonEuro $_{i j t}$ & $\begin{array}{c}-0.5532134^{* * * *} \\
(-6.53)\end{array}$ & $\begin{array}{c}-0.4067741^{* * * *} \\
(-3.07)\end{array}$ & $\begin{array}{c}-0.4532496^{\text {**** }} \\
(-7.26)\end{array}$ & $\begin{array}{c}-0.3843767^{* * * *} \\
(-3.98)\end{array}$ \\
\hline $\max G D P_{i t}$ & $\begin{array}{c}3.04 \mathrm{e}-10^{* * * *} \\
(6.64)\end{array}$ & $\begin{array}{c}3.18 \mathrm{e}^{-10} \\
(0.90)\end{array}$ & $\begin{array}{l}2.03 \mathrm{e}^{-10^{* * * *}} \\
\quad(6.27)\end{array}$ & $\begin{array}{l}5.17 \mathrm{e}^{-11} \\
(0.20)\end{array}$ \\
\hline $\min G D P_{j t}$ & $\begin{array}{c}-3.70 \mathrm{e}^{-11} \\
(-0.40)\end{array}$ & $\begin{array}{c}-1.49 \mathrm{e}^{-11} \\
(-0.04)\end{array}$ & $\begin{array}{c}-4.74 \mathrm{e}^{-12} \\
(-0.07)\end{array}$ & $\begin{array}{c}-1.53 \mathrm{e}^{-10} \\
(-0.58)\end{array}$ \\
\hline $\mathrm{R}^{2}$ & $16.59 \%$ & $25.18 \%$ & - & - \\
\hline $\begin{array}{l}\text { Log-likelihood } \\
\text { Fixed effects }\end{array}$ & $\begin{array}{c}- \\
\text { No }\end{array}$ & $\begin{array}{c}- \\
\text { Yes }\end{array}$ & $\begin{array}{c}-985.2366193 \\
\text { No }\end{array}$ & $\begin{array}{c}-959.3402457 \\
\text { Yes }\end{array}$ \\
\hline Sample size & 2025 & 2025 & 2025 & 2025 \\
\hline
\end{tabular}

Notes: $* * *, * *$ and $*$ indicate that coefficients are significantly different from zero at the $1 \%, 5 \%$ and $10 \%$ levels respectively.

T-statistic is in parentheses.

From Table 2, the income-distribution-overlap variable, OverlapWijt, has a positive effect on total intra-tourist trade and the coefficient is significant with the fractional logit estimator. For any two countries, the more similar are the incomedistribution patterns (in terms of average income by decile) and the greater is the intensity of IIT. When it comes to distinguishing between horizontal and vertical intra-trade (Table 3 and Table 4), the Overlap $W_{i j t}$ variable has a positive effect only on VIIT in tourism, whether or not there are fixed effects. This is what we expect as a result for the manufacturing sector ${ }^{37}$. This variable also extends as an essential determinant to VIIT in tourism. Durkin and Krygier (2000), Gabrisch (2006), and Jensen and Lüthje (2009) are among the few researchers whose econometric studies assign an important role to differences in income distribution in explaining VIIT $^{38}$. The income-distribution

37 The theoretical foundations are derived from the Flam and Helpman model discussed in section II.

38 In Durkin and Krygier, for example, the overlap variable contains the percentage of population earning a higher income than the first quintile in the USA. Our variable operates in deciles and allows comparisons between any two countries. 
overlap, as specified $^{39}$ in our article, shows a positive effect exclusively on VIIT (while it is insignificant for HIIT) in tourism and supports the conclusions of the above mentioned articles. This important result supports the separation of horizontal and vertical determinants of IIT in the tourism sector. Therefore, the use of this overlap variable, which is easy to construct and is the main feature of this article, can be extended to other fields of studies and may apply to other sectors.

As we expect from the literature dealing with the manufacturing sector, $D G D P C_{i j t}$ has different impacts on the two components of IIT. In the case of HIIT, there is a significantly negative relationship without the fixed-effect variables. As suggested by Linder, this can be explained by the fact that similar representative demands (and similarity of consumer tastes) favour horizontal intra-tourist trade. For VIIT in tourism, the $G D P C_{i j t}$ variable has a positive impact when we introduce fixed-effects variables. Theoretical foundations, as well as empirical findings of the link between $D G D P C_{i j t}$ and VIIT, were discussed in section II. If we consider, for instance, that differences in GDP per capita reflect differences in factor endowments, then these differences induce countries to specialize in the production of different ranges of quality products $^{40}$. As, to some extent, trading partners in Europe share similar factor endowments, we would expect to find a nonambiguous relationship with VIIT $^{41}$. Hence, GDP differences have a similar effect on the tourism industry as are commonly observed in the manufacturing sector.

The coefficients estimated for the tourismendowment-difference variables are not significant in most cases. However, two results should be noted. First, the variable Diffendol $I_{i j t}$ (number of historical and cultural sites) has a negative impact on the HIIT when there are no fixed effects. The negative relationship associated with this variable suggests that differences in inherited tourism endowments can induce trade imbalance in similarquality tourist flows. Second, the other endowmentdifference variable related to the number of rainy days, Diffendo $2_{i j t}$, has a positive effect on VIIT in tourism, which is more surprising. One possible interpretation of these results is that differences of tourism specialization in ranges of quality may

Durkin and Krygier, when working with deciles, still refer to the USA for comparisons.

${ }^{39}$ The specification was discussed earlier in section IV.

${ }^{40}$ The same reasoning applies when we consider differences in technology, as in the Flam/Helpman model.

${ }^{41}$ Differences are not too large to induce nonmonotonic impacts on VIIT, depending on the trading partner, as discussed by Cabral et al. (2013) and noted in section II. partially compensate for the difference in climate between countries. For example, climate conditions will always be different in Germany compared to Spain. In order to compensate for unfavourable weather conditions, a country like Germany will endeavour to pay more attention to high-quality tourism services. Besides investing in corresponding infrastructure, regular scheduled events (festivals, art exhibitions, conferences etc.) may be recommended to enhance tourism attractiveness. Tourism endowments have a crucial role on the balance of tourist flows and on the choice of specialization.

The geographic distance variable, Dist $t_{i j}$, is often very significant at the $1 \%$ level and has a negative effect on all forms of IIT in tourism. This result suggests that geographic distance is an impediment to bilateral trade in tourism. This variable can also encompass other forms of distances such as cultural distance (not always included in the religion dummy variable - as, for example, gastronomy) and political distance. The impact works in the same way as for trade in goods.

The coefficient of the ComRel $_{i j t}$ variable is always positive and very significant whatever the method used and the sample studied. This result indicates that similar countries, in terms of cultural proximity, share a high proportion of IIT in tourism, whatever the differentiation of tourism services. The cultural (and notably religious) heritage is therefore an important factor in bilateral tourism attractiveness, because it can represent historic proximity or similarity in consumers' behaviour.

The dummy variable, ZonEuro $_{i j t}$, has a negative effect on the intensity of VIIT in tourism. This surprising result could be interpreted in the following way: exchanges of tourism services at different levels of qualities seem to be favoured between countries with different currencies and probably different levels of cost of living. It shows no significant effects on HIIT. The common currency does not appear to enhance two-way flows of tourism across Europe. This result runs in the opposite direction for manufactured goods.

As expected for manufactured goods, MaxGDP $P_{i j t}$ also has a positive effect on global and vertical intra-tourism trade. For the manufacturing sector, the size of the economy matters. A given product is more likely to be manufactured in a large economy, 
due to the wider range of industries. At the same time, for VIIT to occur for a given product, both trading partners (as discussed in section II) should produce this. Therefore, VIIT is more likely to be observed when trading partners have a large production sector. Economies with large tourism sectors may likewise engage in trade in vertically differentiated items ${ }^{42}$. Surprisingly, this variable also shows a positive effect on the HIIT.

On one hand, we also observe that $\operatorname{MinGDP}_{i j t}$ has a negative effect on the VIIT. On the other hand, there is a positive effect on HIIT and a negative effect on the global IIT only when there are no fixed effects. These signs are the opposite of those predicted for trade in manufactured goods. One plausible explanation is provided by the distinctive feature of tourism consumption. Contrary to other trades, consumers are mobile across countries, whereas tourist goods are not. These issues need further investigation.

\section{Conclusion}

Our econometric investigation extends the empirical observations found in Nowak et al. (2012), describing the pattern of tourism trade in Europe. The main concern of the article is to test trade-theory predictions regarding the determinants of vertical and horizontal IIT for this sector of the economy. The two alternative estimation techniques used - GLS logistic function and the fractional logit model - add a degree of robustness to the findings.

Our results show that GDP per capita, incomedistribution overlap, cultural proximity and geographic distance are the most significant driving forces behind VIIT for European countries. These results confirm trade-theory predictions and most of the empirical findings related to the pattern of VIIT for the manufacturing sector. To a large extent, tourism specialization in most developed countries shares the same determinants as IIT of commodities. However, and contrary to trade in manufactured goods, the common currency has no significant impact on IIT in tourism, surprisingly. As expected, we find that determinants of VIIT cannot explain HIIT in tourism.

\footnotetext{
${ }^{42}$ At the same time, large economies (i.e. those with high GDP) may have a poor tourism sector (scarce tourism endowments). Two-way trade in tourism is less likely to occur between these countries.
}

The study also accounts for specific tourism endowments. Historical sites are not significant for IIT in general, whereas weather conditions have a positive impact exclusively on VIIT, unexpectedly. Difficulties in collecting accurate data for these variables may partly explain these results. Finally, the minimum and maximum GDP variables may have the opposite sign to that predicted for trade in manufactured goods.

Determinants of IIT are to be investigated both in the demand and supply side of the economy. Tourism trade is made up of complex bundles of differentiated services with varying characteristics. These may be combined with other sectors' activities to offset poor natural endowments (such as weather conditions) and induce quality specialization. They may otherwise magnify the effects of natural and historical resources, providing either a wider scope of characteristics or a narrow range of high-quality services.

The Provence Region in France provides such an example of cultural events. The cities of Orange and Avignon both combine weather conditions and historical monuments suited to their summer-season festivals. At the same time, Aix-en-Provence, without the same level of infrastructure or historical endowments, hosts a world-famous open-air Festival of Lyric $\mathrm{Art}^{43}$. Besides the dry summer weather, its attractiveness also relies on organizational skills in offering a very high-quality (and accordingly highly priced) cultural service. These same tourists encountered in the south of France are likely to be seen attending the Bayreuth opera festival in Germany, which is also a specialized and very high-quality cultural product. The endowments are, however, linked to a longstanding tradition, and, of course, to highly skilled staff who perform and organize such an event.

There is intra-tourism trade between these two European countries in cultural services because of similar demand and income, but the supply side of the explanation is made up of different combinations of components, which combine to explain the attractiveness of each country. Intratourism trade is likely to follow the trend observed in manufactured goods. Attention should be paid to various assortments of services and characteristics appearing in tourism destinations. Adapted methods and new tools are needed in investigating this field of international trade.

\footnotetext{
43 The Roque-d'Anthéron piano festival, also in Provence, is located in a small place that lacks accommodation; endowments here comprise only the chateau, good weather conditions and great scenic beauty.
} 


\section{References}

Abd-el-Rahman, K. S. (1986) Réexamen de la définition et de la mesure des échanges croisés de produits similaires entre les nations, Revue économique, 37, 89-116.

Abd-el-Rahman, K. S. (1991) Firms Competitive and National Comparative Advantage as Joint Determinants of Trade Competition, Weltwirtschaftliches Archiv/ Review of World Economics, 127, 83-97.

Aturupane, C., Djankov S. and Hoekman, B. (1999) Horizontal and vertical IIT between Eastern Europe and the European Union, Weltwirtschaftliches Archiv, 135, 62-81.

Azhar, A.K.M. and Elliott, R.J.R. (2006) On the Measurement of Product Quality in IIT, Review of World Economics, 142, 476-495.

Balassa, B. A. (1966) Tariff Reductions and Trade in Manufactures among Industrial Countries, American Economics Review, 56, 466-473.

Balassa, B. and Bauwens, L. (1987) Intra-industry Specialisation in a Multi-country and Multiindustry Framework, The Economic Journal, 97, 923-939.

Blanes, V. and Martin, C. (2000). The nature and causes of intra-industry trade. Back to the comparative advantage explanation? The case of Spain. Review of World Economics/Weltwirtschaftliches Archiv, 136(3), 423-441.

Cabral, M., Falvey, R. and Milner, C. (2013). Endowment differences and the composition of intra-industry trade, Review of International Economics, 21(3), 401-418.

Crespo, N. and Fontoura, M.P. (2004), Intraindustry trade by types: What can we learn from Portuguese data?, Weltwirtschaftliches Archiv, 140, 52-79.

Disdier, A-C., Silvio, T, Fontagné, L and Mayer, T., 2010, "Bilateral Trade of Cultural Goods" Review of World Economics, 145, 575-595.

Durkin, J T and Krygier M. (1997) Empirical analysis of intra-industry trade: a vertically differentiated approach, Purdue University
Durkin, J T and Krygier, M. (2000) Differences in GDP Per Capita and the Share of IIT: The Role of Vertically Differentiated Trade, Review of International Economics, 8, 760-775.

Eicker, F. (1963) Asymptotic Normality and Consistency of the Least Squares Estimators for Families of Linear Regressions, The Annals of Mathematical Statistics, 33, 447-456.

Falvey, R. and Kierzkowski, H. (1987) Product Quality IIT and (Im)perfect Competition, Protection and competition in International Trade, Oxford: Blackwell.

Felbermayr, G. J. and Toubal, F. (2010) Cultural proximity and trade, European Economic Review, 54, 279-293.

Finger, J.-M. (1967) Trade Overlap and the Theory of International Specialisation: A statistical Study of the Hecksher Ohlin and Linder Theories as Alternative Hypotheses, University of North Carolina.

Flam, H. and Helpman, E. (1987) Vertical Product Differentiation and North-South Trade, American Economic Review, 77, 810.

Fontagné, L. and Freudenberg, M. (1997) IIT: Methodological Issues Reconsidered, Working papers in Economics No. 97-01, CEPII.

Fontagné, L., Freudenberg M. and Peridy, N. (1997) Trade Patterns Inside the Single Market, Working papers in Economics No. 1997-01, CEPII.

Fukao.K , Ishido.H and Ito.K. (2003) Vertical intra-industry trade and foreign direct investment in East Asia, Journal of the Japanese and international economies, 17, 468-506

Gabrisch, H. (2006) Vertical IIT between EU and Accessions Countries, IWH-Discussion Papers, No 12-06.

Greenaway, D., Hine R.C. and Milner, C.R. (1994) Country Specific Factors and the Pattern of Horizontal and Vertical Industry in the UK, Weltwirtschaftliches Archiv/Review of World Economics, 130, 77-100.

Greenaway, D., Hine R. C. and Milner, C. R. (1995) Vertical and Horizontal IIT: A cross Country Analysis for the United-Kingdom, Economic Journal, 105, 1505-1518. 
Grubel, H. G. and Lloyd, P. J. (1975) IIT. The theory and Measurement of International Trade in Differentiated Products, Macmillan Press, London.

Gullstrand. J. (2000) Country specific determinants of vertical intra-industry trade with application to trade between Poland and EU, B. Wawrzynjak (ed).

Helpman, E. and Krugman, P. R. (1985), Market Structure and Foreign Trade, Cambridge, MIT Press.

Helpman, E. (1981) International trade in the presence of product differentiation, economies of scale and monopolistic competition: A Chamberlin-Heckscher-Ohlin approach, Journal of International Economics, 11, 305-340.

Hummels, D. and Levinsohn, J. (1995) Monopolistic Competition and International Trade: Reconsidering the Evidence, Quarterly Journal of Economics, 110,799-836.

Jensen, L. and Lüthje, T. (2009) Driving Forces of Vertical Intra-Industry Trade in Europe 19962005, Weltwirtschaftliches Archiv, 145, 469-488.

Krugman, P.R. (1979) Increasing returns, monopolistic competition, and international trade, Journal of International Economics, 9, 469-479.

Krugman, P.R. (1980) Scale Economies, Product Differentiation, and the Pattern of Trade, American Economic Review, 70, 950-959.

Krugman, P.R. (1981) Intra-industry Specialization and the Gains from Trade, Journal of Political Economy, 89, 959-973.

Lancaster, K. (1980) Intra-industry trade under perfect monopolistic competition, Journal of International Economics, 10, 151-75.

Lee, H.H., and Lloyd, P. J. (2002), IIT in Services, Macmillan Press, London.

Lejour, A. and Verheijden, J.W. de P. (2004) Services trade within Canada and the European Union; what do they have in common?, CPB Discussion Paper, No 42.
Li, D., Moshirian, F. and Sim, A. B. (2003) The determinants of IIT in Assurance services, The Journal of Risk and Insurance, 70, 269-287.

Linder, S. B. (1961) An essay on trade and transformation, John Wiley and Sons, New-York.

Loertscher, R. and Wolter, F. (1980) Determinants of IIT: Among countries and across industries, Weltwirtschaftliches Archiv, 116, 280-293.

Martin-Montaner, J. A. and Rios, V. O. (2002). Vertical specialization and intra-industry trade: The role of factor endowments, Weltwirtschaftliches Archiv/Review of World Economics, 138(2), 340-365.

Michaely, M. (1962) Concentration in International Trade, Amsterdam.

Nowak, J-J., Petit, S. and Sahli, M. (2012) IntraTourism Trade in Europe, Tourism Economics, 18, 1287-1311.

Papke, L.E. and Wooldridge, J.M. (1996) Econometric methods for fractional response variables with an application to 401(k) plan participation rates, Journal of Applied Econometrics, 11, 619-632.

Tang, L. (2003) The determinants of international telephone traffic imbalances, Information Economics and Policy, 15, 127-145.

Verdoorn, P. J. (1960) The Intra-Bloc Trade of Benelux, Economics Consequences of the size of Nations, Macmillan Press, London, pp.291-239.

Webster, A., Fletcher, J. and Morakabati, Y. (2007) Tourism and empirical applications of international trade theory: a multi-country analysis, Tourism Economics, 13, 657-674.

White, H. (1980) A Heteroskedasticity-Consistent Covariance Matrix Estimator and a Direct Test for Heteroskedasticity, Econometrica, 48, 817-838. 